KOMPETENSI GURU BERKUALITAS MENGHASILKAN SUMBER DAYA MANUSIA YANG BERKUALITAS

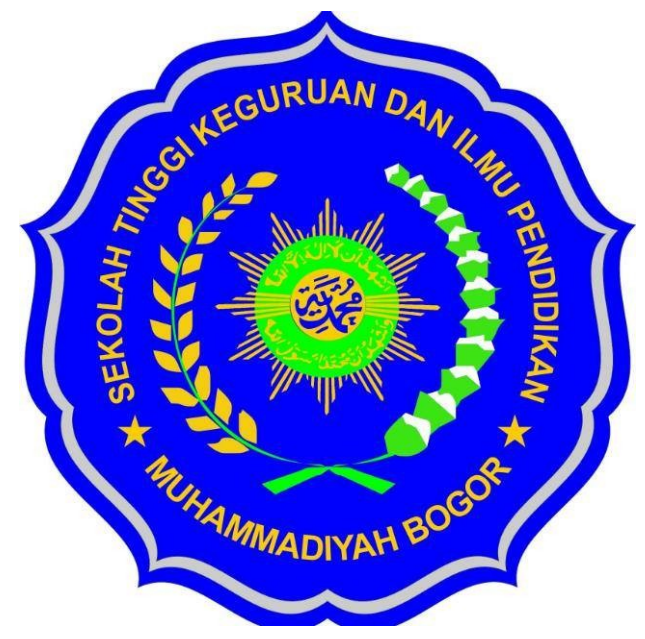

DOSEN PEMBIMBING

Wahyu Bagja Sulfemi, M.Pd

$\underline{\text { Disusun oleh }}$

RENA RIPAHIYAH

STKIP MUHAMMADIYAH BOGOR

PROGRAM STUDI ADMINISTRASI PENDIDIKAN

TAHUN 2019 


\title{
KOMPETENSI GURU BERKUALITAS MENGHASILKAN SUMBER DAYA MANUSIA YANG BERKUALITAS
}

\author{
Rena Ripahiyah \\ STKIP Muhammadiyah Bogor \\ Heriripahiyah@gmail.com
}

\section{A. MATERI}

\section{PENGERTIAN KOMPETENSI GURU}

Pendidikan merupakan usaha sadar dan terencana dalam mewujudkan proses pembelajaran dan suasana belajar agar peserta didik secara aktif mengembangkan potensi diri untuk memiliki kekuatan spiritual, keagamaan, pengendalian diri, kecerdasan, kepribadian, berakhlak mulia, serta memiliki keterampilan yang diperlukan peserta didik, ketiaks bermasyarakat, bangsa dan negara. (Sulfemi dan Minati, 2018 : 151-158).

Dalam pendidikin tak lepas dari peran seorang guru. Guru disebut juga pendidik, bertugas untuk mendidik yang menjadi peserta didik sesuai dengan peraturan pendidikan nasional. Guru merupakan pemeran utama dalam pendidikan , seorang guru harus dapat melakukan berbagai hal dalam waktu bersamaan demi menunjang terlaksananya pendidikan yang baik. Guru minimal harus memilki kemampuan dasar sebagai modal mengahadapi peserta didik di sekolah. Seorang guru harus memahami sikap keterampilan yang dimilki peserta didik. Maka tak salah guru di sebut sebagai tenaga professional, mampu mengerjakan berbagai macam pekerjaan, mampu bersaing dengan waktu, dan mampu mengahsilkan generasi yang berkaulitas dari hasil pembelajaran yang dilaksanakan.

Guru adalah tenaga profesional dituntut menjadi manusia yang berdedikasi tinggi, loyal, berkemauan keras, memiliki etos kerja yang tinggi, bermotivasi tinggi dan berdisiplin yang dapat mendukung berhasilnya visi dan misi suatu sekolah sebagai organisasi. (Sulfemi, $2017: 1-8$ ).

Dalam pelaksanaan tugasnya guru harus memiliki kemampuan dasar sebagai seorang guru, yang mana kemampuan ini dapat menunjang dalam 
menjalankan peran sebagai guru. "kemampuan dasar guru mencakup semua ilmu pengetahuan, keterampilan serta sikap yang harus dan dapat dilakukakan guru dalam penyelenggaraan proses belajar mengajar". (Sulfemi, 2016 : 62-77).

Dalam UU guru dan dosen, BAB I (Ketentuan Umum) pasal 1 ayat 10 bahwa pengertian kompetensi adalah seperangkat pengetahuan, keterampilan, dan perilaku yang harus dimiliki, dihayati, dan dikuasai oleh guru atau dosen dalam melaksanakan tugas keprofesionalan (Sulfemi, 2015 : 71-83).

kompetensi guru dapat diartikan sebagai kebulatan pengetahuan, keterampilan dan sikap yang diwujudkan dalam bentuk perangkat tindakan cerdas dan penuh tanggung jawab yang dimiliki seseorang guru untuk memangku jabatan guru sebagai profesi. (Sulfemi, $2016: 62-77) \quad$ Kompetensi profesionalisme guru dan mutu institusi pendidikan, dengan demikian menjadi suatu keharusan mutlak serta sekaligus menjadi pasword atau kata kunci untuk melahirkan putraputri bangsa yang beradab, produktif, kreatif, inovatif dan efektif. Cita dan harapan kelahiran manusia beradab tersebut di atas seharusnya lahir dari suatu institusi pendidikan yang berstandar nasional (SNPI) dan bahkan internasional, serta kerangka kurikulum nasional Indonesia (KKNI). (Sulfemi, 2016 : 62-77).

\section{MACAM MACAM KOMPETENSI GURU}

Upaya peningkatkan sumberdaya manusia yang berkualitas, bidang pendidikan memegang peranan penting karena pendidikan akan dapat mengembangkan kemampuan serta meningkatkan mutu kehidupan bangsa Indonesia. Disamping itu akan terwujud sumber daya manusia yang terampil, potensial dan berkualitas sebagai pelaksana pembangunan dalam mewujudkan tujuan Nasional. Arsyad dan Sulfemi, $2018: 41-46$ )

\section{Kompetensi Pedagogik}

Pedagogik aialah ilmu yang memepelajari masalah membimbing peserta didik kearah tujuan tertentu, supaya dia mampu menyelesaikan tugas hidupnya. Kompetensi pedagogik yaitu kemampuan yang harus dimiliki pendidik/guru mengenai karakteristik siswa dari aspek seperti moral, emosisonal dan intelektual. Kompetensi pendagogik pun dapat diartikan sebgai kemampuan seorang pendidik 
dalam mengajar di sekolah. Kompetensi pedagogik merupakan kemampuan dalam mengelola pembelajaran peserta didik, yang meliputi: a) pemahaman peserta didik, b) perancang dan pelaksanaan pembelajaran, c) evaluasi pembelajaran dan, d) pengembangan peserta didik untuk mengaktualisasi berbagai potensi yang dimilikinya.Kompetensi pedagogik yaitu kemampuan seorang guru dalam mengelola proses pembelajaran peserta didik. Selain itu kemampuan pedagogik juga ditunjukkan dalam membantu, membimbing dan memimpin peserta didik. (Sulfemi, $2015: 71-83$ ).

Kemampuan yang harus dimiliki guru dengan saspek- aspek pedagogic sebagai berikut :

1. Penguasaan terhadap karakteristik peserta didik dari asepek fisik, moral, sosial, kultur, emosional dan intelektual.

2. Penguasaan terhadap teori belajar dan prinsip - prinsip pembelajaran yang mendidik.

3. Mampu mengembangkan kurikulum yang terkait dengan bidang pengembangan yang diampu.

4. Menyelenggarakan kegiatan pengembangan yang mendidik.

5. Memanfaatkan teknologi informasi dan komunikasi untuk kepentingan penyelenggaraan kegiatan pengembangan mendidik.

6. Memfasilitasi pengembangan potensi peserta didik untuk mengaktualisasikan berbagai potensi yang dimiliki.

7. Berkomunikasi secara efektif, empatik, dan santun dengan peserta didik.

8. Melakukan penilain dan evaluasi proses dan hasil belajar, memanfaatkan hasil penilaian dan evaluasi untuk kepentingan pembelajaran.

9. Melakuakan tindakan reflektif untuk peningkatan kualitas pembelajaran 


\section{Kompetensi kepribadian}

Kompetensi kepribadian adalah kompetensi yang berkaitan dengan tingkah laku pribadi guru itu sendiri yang kelak harus memiliki nilai - nilai lluhur sehingga terpantul dalam perilaku sehari-hari. Berhubungan dengan falsafah hidup bahwa guru diharapkan menjadi teladan/model manusia dengan memiliki nilainilai luhur. Setiap guru memilki kepribadian yang berbeda, hal ini yang menyebabkan setiap guru memiliki ciri khas masing masing.

Pada kompetensi keribadian guru harus :

a. Guru harus meningkatkan iman dan ketakwaan kepada tuhan sejalan dengan agama dan kepercayaan yang dianutnya :

b. Grur berbeda dengan masyarakat pada umunya, memilki rasa percaya diri lebih maka seorang guru harus mampu menyelesaikan bergabai persoalann yang dihadapinya.

c. Guru harus mampu mengembangkan sikap tenggang rasa dan toleransi sesame umat beragama sehingga mampu berinteraksi dengan peserta didik dan masyarakat.

d. Guru diharapkan menjadi fasilitatordalam menumbuh kembangkan budaya berpikir di kritis dimasyarakat .

\section{Kompetensi sosial}

Kompetensi sosial merupakan kemampuan guru untuk menyesuaikan diri kepada tuntutan kerja di lingkungan sekitar pada waktu membawakan tugasnya sebagai guru. Peran yang dibawa guru dalam masyarakat berbeda dengan profesi lain. Oleh karena itu, perhatian yang diberikan masyarakat terhadap guru pun berbeda dan ada kekhususan terutama adanya tuntutan untuk menjadi pelopor pembangunan di daerah tempat guru tinggal.

Kompetensi sosial guru sebgai berikut :

1) Bekomunikasi lisan, tulis, dan/atau isyarat secara santun,

2) Menggunakan teknologi komunikasi dan informasi secara fungsional, 
3) Bergaul secara efektif dengan peserta didik, sesama pendidik, tenaga kependidikan, pemimpin satuan pendidikan, orang tua atau wali peserta didik,

4) Bergaul secara santun dengan masyarakat sekitar dengan mengindahkan norma serta sistem nlai yang berlaku, dan

5) Menerapkan perinsip persaudaraan sejati dan semangat kebersamaan

\section{Kompetensi professional}

Merupakan kemampuan dalam penguasaan materi pembelajaran secara luas dan mendalam yang memungkinkannya membimbing peserta didik memenuhi standar kompetensi. Kompetensi professional guru merupakan kompetensi yang menggambarkan kemampuan khusus yang sadar dan terarah kepada tujuan-tujuan tertentu.

Adapun dalam kompetensi ini seorang guru hendaknya mampu untuk:

1) Menguasai materi, struktur, konsep dan pola pikir keilmuan yang mendukung mata pelajaran yang ditempuh.

2) Menguasai standar kompetensi dan kompetensi dasar mata pelejaran/bidang pengembangan yang ditempuh.

3) Mengembangkan materi pembelajaran yang diampu secara kreatif.

4) Mengembangkan keprofesionalan serta berkelanjutan dengan melakuan tindakan reflektif.

5) Memanfaatkan teknologi informasi dan komunikasi untuk berkomunikasi dan mengembangkan diri. (Sulfemi, 2015 : 71-83).

\section{KESIMPULAN}

kompetensi guru dapat diartikan sebagai kebulatan pengetahuan, keterampilan dan sikap yang diwujudkan dalam bentuk perangkat tindakan cerdas dan penuh tanggung jawab yang dimiliki seseorang guru untuk memangku jabatan guru sebagai profesi.Ketika guru memiliki kompetensi yang baik maka akan menghsilkan peserta didik yang berkualitas juga. Kompetensi profesionalisme guru dan mutu institusi pendidikan, dengan demikian menjadi suatu keharusan mutlak serta sekaligus menjadi pasword atau kata kunci untuk melahirkan putraputri bangsa yang beradab, produktif, kreatif, inovatif dan efektif. Cita dan harapan kelahiran manusia beradab tersebut di atas seharusnya lahir dari suatu institusi pendidikan yang berstandar nasional (SNPI) dan bahkan internasional, serta kerangka kurikulum nasional Indonesia (KKNI). 


\section{DAFTAR PUSTAKA}

Sulfemi, Wahyu Bagja. (2015). Kemampuan Pedagogik Guru. Prosiding Seminar Nasional. STKIP Muhammadiyah Bogor 1. (1). 71-83.

Sulfemi, Wahyu Bagja. (2016). Kompetensi Profesionalisme Guru Indonesia dalam Menghadapi MEA. Prosiding Seminar Nasional STKIP Muhammadiyah Bogor. 1 (1), 62-77.

Sulfemi, Wahyu Bagja. (2017). Analisis Pengaruh Motivasi Dan Disiplin Terhadap Kinerja Guru (Studi Kasus di SMA Negeri 1 Pamijahan Kabupaten Kabupaten Bogor). Prosiding Seminar Nasonal STKIP Muhammadiyah Bogor. 1 (1), 342-357.

Arsyad, Arsyad dan Sulfemi, Wahyu Bagja. (2018) Metode Role Playing Berbantu Media Audio Visual Pendidikan dalam Meningkatkan Belajar IPS. Jurnal Pendidikan Ilmu Pengetahuan Sosial Indonesia. 3 (2). 41 - 46.

Sulfemi, Wahyu Bagja dan Hilga Minati. (2018). Meningkatkan Hasil Belajar Peserta Didik Kelas 3 SD Menggunakan Model Picture And Picture dan Media Gambar Seri. JPSD. 4 (2), 228- 242.

https://www.gurupendidikan.co.id/kompetensi-guru/ 


\section{Soal Pg}

1. Keahlian dan kemampuan seorang guru di sebut juga..
A. Kompetensi
C. Kuantitas
B. Kompeten
D. Kualitas

2. Tenaga professional di dunia pendidikan disebut
A. Guru
C. Tata Usaha
B. Perpustakawan
D. Kepala Sekolah

3. Semua kemampuan yang minimal harus dimiliki adalah
A. Kompetensi dasar
C. Kemampuan dasar
B. Keahlian Dasar
D. Keterampilan

4. Guru termasuk kedalam
A. Tenaga Kependidikan
C. Kependidikan
B. Pendidik
D. Tenaga didik

5. Kompetensi guru kecuali..
A. Kompetensi Pedagogik
C. Kompetensi Propesional
B. Kompetensi Kepribadian
D. Kompetensi Keahlian

6. Kompetensi tetnag seorang guru mampu memahami pembelajaran merupakan..
A. Kompetensi Pedagogik
C. Kompetensi Propesional
B. Kompetensi Kepribadian
D. Kompetensi Keahlian

7. Kompetensi yang berhubungan dengan akhlak dan perilaku guru merupakan...
A. Kompetensi Pedagogik
C. Kompetensi Propesional
B. Kompetensi Kepribadian
D. Kompetensi Keahlian

8. Kompetensi yang berhubungan dengan bagaimana cara guru berinteraksi merupakan..
A. Kompetensi Pedagogik
C. Kompetensi Propesional
B. Kompetensi Kepribadian
D. Kompetensi Sosial

9. Kompetensi dengan kemampuan guru menguasai materi pembelajaran merupakan
A. Kompetensi Pedagogik
C. Kompetensi Propesional
B. Kompetensi Kepribadian
D. Kompetensi Keahlian

10. Guru harus memiliki percaya diri dan meningkatkan keimanan kepada tuhan sesuai agama yang dianutnya merupakan Kompetensi..
A. Kompetensi Pedagogik
C. Kompetensi Propesional
B. Kompetensi Kepribadian
D. Kompetensi Keahlian

\section{ESSAY}

1. Sebutkan pengertian Kompetensi Guru

2. Kompetensi guru masuk kedalam standar 
3. Sebutkan kompetensi guru

4. Kompetensi pedagogik adalah

5. Kompetensi Kepribadian adalah..

\section{JAWABAN \\ PG}

$\begin{array}{lr}\text { 1.A } & 6 . \mathrm{A} \\ \text { 2.A } & 7 . \mathrm{B} \\ \text { 3. C } & 8 . \mathrm{D} \\ \text { 4. B } & 9 . \mathrm{C} \\ \text { 5.D } & 10 . \mathrm{B}\end{array}$

\section{ESSAY}

1. kompetensi guru dapat diartikan sebagai kebulatan pengetahuan, keterampilan dan sikap yang diwujudkan dalam bentuk perangkat tindakan cerdas dan penuh tanggung jawab yang dimiliki seseorang guru untuk memangku jabatan guru sebagai profesi.

2. Standar pendidik dan tenaga kependidikan

3. Kompetensi, pedagogic, kepribadian, sosial, professional

4. Kompetensi pedagogik yaitu kemampuan yang harus dimiliki pendidik/guru mengenai karakteristik siswa dari aspek seperti moral, emosisonal dan intelektual.

5. Kompetensi kepribadian adalah kompetensi yang berkaitan dengan tingkah laku pribadi guru itu sendiri yang kelak harus memiliki nilai - nilai lluhur sehingga terpantul dalam perilaku sehari-hari. Berhubungan dengan falsafah hidup bahwa guru diharapkan menjadi teladan/model manusia dengan memiliki nilai- nilai luhur. 